\title{
EVALUATION OF Xylella fastidiosa GENETIC DIVERSITY BY fAFLP MARKERS ${ }^{1}$
}

\author{
LUCIANO TAKESHI KISHI², ESTER WICKERT ${ }^{2}$, ELIANA GERTRUDES DE MACEDO LEMOS²
}

ABSTRACT -The first phytopathogenic bacterium with its DNA entirely sequenced is being detected and isolated from different host plants in several geographic regions. Although it causes diseases in cultures of economic importance, such as citrus, coffee, and grapevine little is known about the genetic relationships among different strains. Actually, all strains are grouped as a single species, Xylella fastidiosa, despite colonizing different hosts, developing symptoms, and different physiological and microbiological observed conditions. The existence of genetic diversity among $X$. fastidiosa strains was detected by different methodological techniques, since cultural to molecular methods. However, little is know about the phylogenetic relationships developed by Brazilian strains obtained from coffee and citrus plants. In order to evaluate it, fAFLP markers were used to verify genetic diversity and phylogenetic relationships developed by Brazilian and strange strains. fAFLP is an efficient technique, with high reproducibility that is currently used for bacterial typing and classification. The obtained results showed that Brazilian strains present genetic diversity and that the strains from this study were grouped distinctly according host and geographical origin like citrus-coffee, temecula-grapevine-mulberry and plum-elm.

Index terms: fAFLP, Xylella fastidiosa, genetic diversity, DNA fingerprinting.

\section{DIVERSIDADE GENÉTICA DE Xylella fastidiosa AVALIADA POR MARCADORES fAFLP}

RESUMO-A primeira bactéria fitopatogênica a ter seu genoma totalmente seqüenciado foi detectada e isolada em diferentes hospedeiros em diferentes regiões geográficas. Embora seja causadora de doenças em culturas economicamente importantes, como citros, cafeeiro e videira, pouco se conhece acerca das relações genéticas estabelecidas entre isolados da bactéria. Atualmente, todos os isolados são agrupados como uma única espécie, Xylella fastidiosa, apesar de colonizarem diferentes hospedeiros que desenvolvem sintomas diferenciados e possuir diferentes condições fisiológicas e microbiológicas. A existência de diversidade genética entre isolados da bactéria foi detectada da por métodos culturais e moleculares, embora pouco se conheça acerca das relações genéticas de isolados brasileiros obtidos de citros e cafeeiro. Este trabalho teve por objetivo verificar, através de marcadores moleculares fAFLP a existência de diversidade genética e as relações filogenéticas estabelecidas pelos isolados das bactérias brasileiras e estrangeiras. Estes marcadores foram selecionados por sua alta reproducibilidade e por ser de uso comum para tipagem e classificação bacteriana. Os resultados obtidos mostraram que os isolados brasileiros apresentam diversidade genética e que os isolados deste estudo agruparamse de acordo com o hospedeiro e origem geográfica, a saber, citros-cafeeiro, temécula-videira-amoreira e ameixeira-elmo.

Termos para indexação: fAFLP, Xylella fastidiosa, diversidade genética, marcadores de DNA.

\section{INTRODUCTION}

Xylella fastidiosa is a fastidious gram-negative and xylem-limited bacterium (Wells et al. 1987) that causes a range of economically important plant diseases, including citrus variegated chlorosis (CVC - Rossetti et al. 1990), Pierce's disease (PD) of grapevine, alfalfa dwarf, leaf scorch of almond, coffee, elm, sycamore, oak, plum, mulberry, maple, and oleander, and periwinkle wilt (Purcel \& Hopkins, 1996).

$\mathrm{CVC}$ is a major problem in Brazil, where over 70 million sweet orange trees (34\%) are affected. The disease also occurs in Argentina, under the name "pecosita" (Contreras, 1992; Garnier et al.1993). CVC affects all commercial sweet orange varieties and the affected fruits are small and hardened and so, do not have commercial value. The fast dissemination of CVC comes mainly by the use of infected nursery trees and by the transmission of $X$. fastidiosa by several xylem-feeding sharpshooter insect vectors.
The detection and characterization of $X$. fastidiosa strains have been done through classic procedures based on cultivation (Hopkins, 1989) as well as using molecular procedures, such as protein profiling and homology of DNA (Chang and Schaad, 1992), RFLP (Restriction Fragment Length Polymorphism - Chen et al. 1992), PCR (Polymerase Chain Reaction - Minsavage et al. 1994), sequencing of the ITS DNA sequence (Ciapina, 2001), 16S rDNA (Chen et al. 2000) and SNP (Single Nucleotide Polymorphism - Wickert, 2007). But despite their physiologic, microbiologic, pathogenic and molecular differences, all strains are characterized as single species.

Recently, three Xylella subspecies were proposed based in cultural assays, DNA-DNA relatedness and 16S DNA sequence (Schaad et al., 2005). These authors proposed $X$. fastidiosa subsp piercei, $X$. fastidiosa subsp multiplex and $X$. fastidiosa subsp pauca as new subspecies.

Amplified restriction fragment length polymorphism (AFLP) is a technique developed for the fingerprinting of plant, bacterial, fungal, and nematode genomes (Vos et al. 1995;

(Trabalho 070-07). Recebido em: 21-03-2007. Aceito para publicação em: 20-07-2007.

${ }^{2}$ Departamento de Tecnologia, Faculdade de Ciências Agrárias e Veterinárias - Universidade Estadual Paulista, Via de Acesso Prof. Paulo D. Castellane, Jaboticabal (SP), 14884-900, Brazil. email: egerle@ffcav.unesp.br

Rev. Bras. Frutic., Jaboticabal - SP, v. 30, n. 1, p. 202-208, Março 2008 
Rademaker et al. 2000). The advantages of this technique in characterizing microbial populations is the extensive coverage of the genome under study and that the complexity of the AFLP fingerprinting can be advantageously managed by adding selective bases to the primers during PCR amplifications (Vos et al. 1995). For the bacterial genome, the AFLP method has been evaluated in microbial taxonomy (Vaneechoutte, 1996), in diversity studies of human pathogenic bacteria (Purcell \& Hopkins 1996), and in characterizing plant pathogenic bacteria at the pathovar level (Bragard et al. 1997, Janssen et al., 1996).

AFLP analysis is a technique based on selective amplification of DNA restriction fragments. It is technically similar to RFLP analysis, except that only a subset of the fragments are displayed and the number of fragments generated can be controlled by primer extensions. AFLP advantage over other techniques is that multiple bands are derived from over all the genome. This prevents overinterpretation or misinterpretation due to point mutations or single-locus recombination, which may affect other genotypic characteristics. The main disadvantage of AFLP markers is that alleles are not easily recognized (Majer et al. 1996).

In its fluorescent form (fluorescent amplified-fragment length polymorphism - fAFLP), one of the PCR primers is fluorophore-labeled making the amplified fragments visible to an automated DNA sequencer. Once the complete genome sequence for Escherichia coli was published (Cole et al. 1998), it was possible to predict the sizes of DNA fragments generated by fAFLP of that species and demonstrate the high experimental fidelity of the technique (Cousins et al. 1998). Genome sequencebased fAFLP analysis of $E$. coli showed accurate fragment sizing (61 bp), reproducibility, high discriminatory power, and added phylogenetic value (Cousins et al. 1998). In addition, the results generated by fAFLP can be stored in databases like AmpliBASE MT (Majeed et al. 2004) which serve as resources for future studies of comparisons, as proposed by Aarts et al. 1999.

Publication of the complete genome sequence of $X$. fastidiosa (Simpson et al. 2000) permits us to design genomebased fAFLP conditions to evaluate genetic diversity for this pathogen and to determine genetic relationships between the studied strains. In this study, we applied fAFLP analysis to $22 X$. fastidiosa strains from citrus (Citrus sinensis), coffee (Coffea arabica), grape (Vitis vinifera), plum (Prunus salicina Lindl), mulberry (Morus alba Lindl) and elm (Ulmus procera) in order to evaluate their genetic diversity and phylogenetic relationships.

\section{MATERIAL AND METHODS}

Bacterial strains and DNA isolation. Twenty-two strains from different hosts were evaluated in the present study, their geographical origin and host species are indicated in Table 1. $X$. fastidiosa cells were grown in PW medium (Davis et al. 1981) for 7 days at $28^{\circ} \mathrm{C}$ in the dark with low-speed, rotatory agitation $(200$ rpm). The genomic DNA extraction from the $X$. fastidios $a$ strains followed the method proposed by Ausubel et al. (1987) with some modifications, which included the addition of $100 \mathrm{uL}$ of RNAse solution $(200 \mathrm{mg} / \mathrm{mL})$ following an incubation at $37^{\circ} \mathrm{C}$ for
$1 \mathrm{~h}$. DNA concentration and quality were determined by comparison with known standards in $0.8 \%$ agarose gels in TBE buffer $(89 \mathrm{mM}$ Tris-base, $89 \mathrm{mM}$ Boric acid, $2 \mathrm{mM}$ EDTA, $\mathrm{pH} 8,3$ ) containing 0.5 $\mathrm{mg} / \mathrm{mL}$ ethidium bromide (Sambrook et al. 1989) and photographed using Gel-Doc 1000 digital photodocumentation equipment (BioRad).

fAFLP markers. The fAFLP markers were developed using fAFLP Microbial Mapping kit (Applied BioSystems part number 402948) according manufacturer instructions. fAFLP-PCR products were added with formamide-loading dye (1.5 $\mathrm{ml}$ final volume) and loaded onto an ABI Prism 377 DNA Sequencer (Applied Biosystems) along with an internal lane standard, GS-500 Rox. Fragment separation was carried out for $2 \mathrm{~h}$ and $30 \mathrm{~min}$ at $51^{\circ} \mathrm{C}, 2.5 \mathrm{kV}$, and $60 \mathrm{~mA}$ using a Long Ranger 5\% gel (Biowhittaker Molecular Applications - BMA) and one time TBE running buffer ( $89 \mathrm{mM}$ Tris, $89 \mathrm{mM}$ borate, $2.5 \mathrm{mM}$ EDTA, $\mathrm{pH}$ 8.3). Fragments were detected and compiled by the ABI Prism Data CollectionTM (Applied Biosystems) software. Gel image files were generated and all the lanes were extracted for making individual electropherograms.

Phylogenetic relationships. Fragment analysis was performed with the Genescan Analysis 3.1 package (Applied Biosystems) with average parameters of smoothing and a baseline of 100 urf. The Genescan ${ }^{\mathrm{TM}}$ data, ranging from the size-marker $100 \mathrm{bp}$ band to the $500 \mathrm{bp}$ band, of individual strains were exported to Genotyper 2.5 (Applied Biosystems) for digitization and genotyping. Patterns were normalized by reference to the molecular mass of the internal ROX-labelled size standard that was included in each sample. Fragments were analyzed from primer combinations and were scored as either present (1) or absent $(0)$ for constructing a binary matrix that was converted in similarity matrix using software PAUP (Phylogenetic Analysis Using Parcimony, version 4.1) (Swofford, 1998). Similarity matrix was exported and used to evaluate phylogenetic relationships by distance method and Neighbor Joining algorithm with MEGA software version 4 (Kumar et al, 2004).

Genetic distances. Values of genetic distance were calculated between groups of bacteria from different hosts and between groups of bacteria obtained from the same host (Table 1) using similarity matrix. Estimates of genetic distances were used to evaluate genetic divergence within and between groups of bacteria. The genetic distance within groups was estimated by the arithmetic mean of all individual pairwise distances between taxas within a group and genetic distance between groups was estimated by the arithmetic mean of all pairwise distances between two groups in the inter-group comparisons. These values were calculated using the neighbor-joining algorithm by the MEGA software.

PCA (Principal component Analysis). Additionally, principal component analysis (PCA), was carried out in the binary data of fAFLP to get the relation enter the strains in a tridimensional space, using 3.1 Multi Variate Statistical Package - MVSP software Vers 1.3. 


\section{RESULTS}

Development of fAFLP markers. fAFLP markers were used in the characterization of the molecular diversity among 22 strains of $X$. fastidiosa (Table 1). In the first step, five strains, 9a5c, U12, 11779, Jab20, and B16, were analyzed with nine selective combinations of primers (EcoRI-AA, EcoRI-AG, MseI-0, MseI-A, MseI-C, MseI-G, MseI-T, MseI-CA) in order to select the Eco/Mse combinations more efficient on showing the genetic diversity. The distribution of banding patterns of the strains ranged from 100 to $500 \mathrm{bp}$ in size. Analysis of the results obtained by the selective primers showed that primers containing selective bases $\mathrm{G}$ or $\mathrm{C}$ were more effective than those containing A or T, because they presented a great diversity of polymorphic bands. In this way, the follow three best combinations of primers were selected to verify the degree of molecular diversity of X. fastidiosa: EcoRI-AG/MseICA, EcoRI-AT/MseI-A, and EcoRI-A/MseI-G.

Phylogenetic relationships. Seventy DNA fragments which were reproducibly detected, ranging from 50 to $500 \mathrm{bp}$, were selected for the analysis of $22 X$. fastidiosa strains. Among these, 35 different DNA fingerprints were identifed. A binary matrix $(22 \times 68)$ was generated of DNA fragments to evaluate the diversity of $X$. fastidiosa strains and the degree of DNA similarity. In the tree that shows the phylogenetic relationships (Figure 1) the 22 strains of $X$. fastidios $a$ are distributed in three different groups. In group A, strains originated from grape (9713, 9715 and 8935), mulberry (6745) and temecula grouped with a similarity around $88 \%$. Strains from plum (9746 and 6747) and elm (6748) formed the Group B showing similarity of $96 \%$. And the strains from citrus ( $9 \mathrm{a} 5 \mathrm{c}, 11779,38868$, Jab20, Jab26, 11348, U12, B16, 12288 and 11037) and coffee (C6, Jab1, Jab2 and Jab14) formed the Group C with a similarity of $86 \%$. Among the Group C, coffee strains grouped preferentially, with a similarity of $92 \%$.

Genetic distances. Genetic distance indexes were estimated for the Group of different-host strains (Table 3), as well as distance indexes for the same-host strains were estimated (Table 4). Genetic distance indexes were calculated to evaluate genetic divergence within and between Groups. So, low values of genetic distance indicate that the organisms or groups are genetically closed, and higher distance values that have great genetic divergence. The greatest genetic distance among strains from the same host was observed for grape (0.31373), followed by coffee $(0.25980)$, and then by citrus $(0.24510)$ and plum (0.07353). This index was not calculated for the other hosts because they are represented by only one strain. Among the Brazilian strains, the greatest genetic distance found between coffee plant strains shows the likely higher genetic diversity of this group, compared to citrus. Regarding genetic distances between groups of strains from different hosts, the lowest value was found for plum and elm (0.00129) followed by Brazilian citrus and coffee strains $(0.28088)$, while the greatest distance was observed between coffee and temecula strains (0.44118). This means that Brazilian strains are genetically close.

Principal coordinate analysis (PCA). PCA is one of the multivariate approaches of grouping based on similarity coefficients or variance-covariance values of the component traits of the entities. It is expected to be more informative about differentiation among major groups, while the cluster-analysis provides higher resolution among closely related populations (Liu et al. 2001). In our PCA analysis, more than $62 \%$ of the variation in the estimate of genetic similarity was explained by the first three components, indicating the suitability of the fAFLP approach for genetic clustering (Figure 2). The strains of Xylella grouped into three distinct groups according their host. Strains of $X$. fastidiosa that formed the Group 1 belongs to citrus-coffee (citrus strains 9a5c, 11779, 38868, Jab20, Jab26, 11348, U12, B16, 11037, 12288, and coffee strains Jab14, Jab2, Jab1 and C6), strains that form Group 2 belongs to plum-elm (plum strains 9746, 6747 and elm 6748)) and strains from group 3 belongs to grapetemecula-mulberry (grape strains $9713,9715,8935$, mulberry 6745 and temecula). These groups are most distinctly separated and were placed on the plane defined by $\mathrm{X}$ and $\mathrm{Y}$ axes, respectively. Citrus and coffee strains formed a group more dispersed than the group formed by plum-elm and grape-temecula-mulberry. But three coffee strains (Jab1, Jab2 and Jab14) form a little aggregate group that can be distinguished from the other strains from the same citrus-coffee group.

\section{DISCUSSION}

The results of these analyses revealed that it was possible to differentiate strains of $X$. fastidiosa from differents hosts using fAFLP markers. The fAFLP analysis revealed great variability within $X$. fastidiosa since 68 fAFLP polimorphics fingerprints were observed for the 22 strains. This value represents around 50 percent of the total of obtained markers (148 markers). So, fAFLP had a good resolution level for differentiation of the strains in groups according hosts. Several DNA fragments were common to all $X$. fastidiosa strains. Other DNA fragments could distinguish the divisions defined by Cook et al. (1989) within $X$. fastidiosa strains or differentiate strains according to their geographical origin and are therefore useful for the development of diagnostic tools and epidemiological studies.

Results obtained by Chen et al. (2000) showed that the strains of X. fastidiosa could be divided into two groups, one group for strains of grape and mulbery and the second group for strains of citrus, oak, grape, plum, and mulberry, based on sequencing of the $16 \mathrm{~S}$ rDNA gene. In this work, it was possible to observe that citrus and coffee strains formed a separate group from the strains from the other hosts. It was also verified that coffee and citrus strains are genetically closer that to the other strains. This can be likely to the fact that only strains from citrus and coffee are Bazilians, as one plum strain (9746) and the other strains are not.

Using SNP markers, Wickert (2007) studied the genetic diversity of $X$. fastidiosa strains from different hosts, such as citrus, coffee, mulbery, plum, and grape, verifying that citrus and coffee strains were genetically closer and phylogenetically related. This was also verified by the results obtained in this work, presenting distinct groups citrus-coffee, grape-mulberrytemecula, and plum-elm. 
The great similarity between coffee and citrus strains can be explained by the fact that these crops are in temporal and geographic proximity, coexisting in regions such as the State of São Paulo, Brazil, which favors the migration of the microorganism from one plant to another. Different works suggested that this microorganism may have migrated from coffee plants to citrus, as previously reported by Coletta-Filho and Machado (2002).

Since citrus and coffee crops coexist temporally and geographically in Brazil, determination of the level of genetic subdivision of $X$. fastidiosa strains from both crops will guide important decisions regarding how to deal with this bacterium. This knowledge will be useful for the control of diseases such as CVC (Variegated Citrus Chlorosis) and CLS (Coffee Leaf Scorch), occurring alone or in association.

The use of fAFLP markers in studies of genetic diversity can provide a better measurement of genetic relationships between strains, and is some cases this fingerprinting technique allowing the taxonomic characterization below the species level (Janssen et al. 1996). Arnold et al. (1999) characterized different strains of Escherichia coli and verified that fAFLP was suitable for epidemiological investigation and provided well-defined and reproducible identifiers of genotype of each strain.In Pseudomonas syringae pv. tomato and P. syringae pv. maculicola, (Clerc et al. 1998) observed that the analysis of data obtained by AFLP was more efficient in evaluating diversity intrapathovar than those obtained using the RAPD technique. In another study, for detecting the genetic variation among 47 ancestries of Xanthomonas axonopodis pv. manihotis, Restrepo et al. (1999) used the AFLP technique and it was verified that the obtained results were solid then those obtained by RFLP using plasmids as probes. However, some primer combinations could differentiate strains that were not discriminated by the analysis of RFLP.

Recently, Chen et al.(2005) based on a DNA-DNA relatedness assay and comparing the 16S DNA sequences of $X$. fastidiosa strains from different hosts, proposed classify Xylella strains as $X$. fastidiosa subsp. piercei (strains from grape, alfafa, maple and almond), X. fastidiosa subsp. multiplex (strains from peach, plum, almond, elm, pigeon grape, sycamore and other shade trees) and as $X$. fastidiosa subsp. pauca (only citrus strains). These authors did not used Temecula, mulberry and coffee strains in their analysis, as we do in this work. In this work, temecula and mulberry strain grouped with grape strains, suggesting belong to $X$. fastidiosa subsp. piercei. In the same way, as citrus and coffee strains could not be separated according to their host, it is likely that Brazilian strains from coffee also belong to $X$. fastidiosa subsp. pauca, as suggested by Schaad et al. (2005).

The use of fAFLP analysis as a method for characterization and evaluation of genetic diversity has the advantage that it can allow species identification and of different organisms, and can also show the relationships and the genetic diversity among organisms from the same species. In this case, the technique can contribute to the definition of taxonomic classification of new and/or recently isolated $X$. fastidios $a$ strains in subspecies, as proposed by Schaad et al. (2005), because it was verified that the groupment of the strains from this work agreed with those obtained by Schaad et al. (2005), despite the fact that some strains from different hosts were used. So, fAFLP markers can be an efficient tool - likely not for determine new species or subspecies - for characterize a species and evaluate phylogenetic relationships, and in some cases, according the obtained results, evaluate the possibility of studies need for proposing new subspecies, like DNA-DNA relatedness and sequencing of conservated genes.

TABLE 1 - Origins of $X$. fastidiosa strains.

\begin{tabular}{|c|c|c|c|}
\hline Strains & Host & Geographical origin & Font \\
\hline $9 \mathrm{a} 5 \mathrm{c}$ & Citrus sinensis & Macaubal, São Paulo, Brazil & INRA $^{a}$ \\
\hline 11779 & Citrus sinensis & (Pinhalzinho, Santa Catarina, Brazil) & IAPAR $^{b}$ \\
\hline 11348 & Citrus sinensis & (Loanda, Paraná, Brazil) & IAPAR \\
\hline Jab 20 & Citrus sinensis & Taiaçu,São Paulo, Brazil & LBMP $^{\mathrm{c}}$ \\
\hline 38868 & Citrus sinensis & São Paulo & LBMP \\
\hline U12 & Citrus sinensis & Cordeirópolis, São Paulo & $\operatorname{CCSM}^{d}$ \\
\hline Jab26 & Citrus sinensis & Jaboticabal, São Paulo & LBMP \\
\hline 11037 & Citrus sinensis & São Paulo & IAPAR \\
\hline B16 & Citrus sinensis & Cordeirópolis, São Paulo & CCSM \\
\hline 12288 & Citrus sinensis & Paraná & IAPAR \\
\hline $\mathrm{C} 6$ & Coffea arabica & Cordeirópolis, São Paulo & CCSM \\
\hline Jabl & Coffea arabica & Garça, São Paulo & LBMP \\
\hline Jab2 & Coffea arabica & Garça, São Paulo & LBMP \\
\hline Jab14 & Coffea arabica & Garça, São Paulo & LBMP \\
\hline 8935 & Vitis vinifera & Flórida, USA & ATCC $35879^{\circ}$ \\
\hline 9713 & Vitis vinifera & Flórida, USA & IAPAR \\
\hline 9715 & Vitis vinifera & Flórida, USA & IAPAR \\
\hline Temécula & Vitis vinifera & Flórida, USA & $\mathrm{AEG}^{\mathrm{f}}$ \\
\hline 9746 & Prunus salicina & Paraná & IAPAR \\
\hline 6747 & Prunus salicina & Georgia & ATCC 35871 \\
\hline 6745 & Morus rubra & Massachusetts & ATCC 35869 \\
\hline 6748 & Ulmus americana & Washington & ATCC 35873 \\
\hline
\end{tabular}

a-INRA, Institut National de la Recherche Agronomique et Universite Victor Ségale, Bordeaux, France. b-IAPAR, Instituto Agronômico do Paraná, Paraná, Brasil. c-LBMP, Laboratório de Bioquímica de Microrganismos e Plantas, UNESP, Jaboticabal, São Paulo, Brasil. d-CCSM, Centro APTA Citros Sylvio Moreira, Instituto Agronômico, Cordeirópolis, São Paulo, Brasil. e-ATCC, "American Type Culture Collection", Manassas. f-Agronomical and Environnmental Genomes - AEG - (FAPESP/ ONSA).

TABLE 2 - Genetic distance among the groups of Xylella fastidiosa same-host strains.

\begin{tabular}{|c|c|}
\hline Host & Average \\
\hline Citrus & 0.24510 \\
\hline Plum & 0.07353 \\
\hline Elm & - \\
\hline Goffee & 0.25980 \\
\hline Temecula & 0.31373 \\
\hline Mulberry & - \\
\hline
\end{tabular}


TABLE 3 - Genetic distance among the groups of Xylella fastidiosa different-host strains.

\begin{tabular}{|l|l|l|l|l|l|l|l|}
\hline & Citrus & Plum & Elm & Coffee & Grape & Temecula & Mulberry \\
\hline Citrus & - & & & & & & \\
\hline Plum & 0.30294 & - & & & & & \\
\hline Elm & 0.36765 & $\mathbf{0 . 1 1 0 2 9}$ & - & & & & \\
\hline Coffee & 0.28088 & 0.37868 & 0.42647 & - & & & \\
\hline Grape & $\mathbf{0 . 4 3 8 2 4}$ & 0.35049 & 0.36275 & 0.42892 & - & & \\
\hline Temecula & 0.39412 & 0.33088 & 0.38235 & 0.44118 & 0.26471 & - & \\
\hline Mulberry & 0.40294 & 0.25735 & 0.25000 & 0.41176 & 0.30882 & 0.30882 & - \\
\hline
\end{tabular}

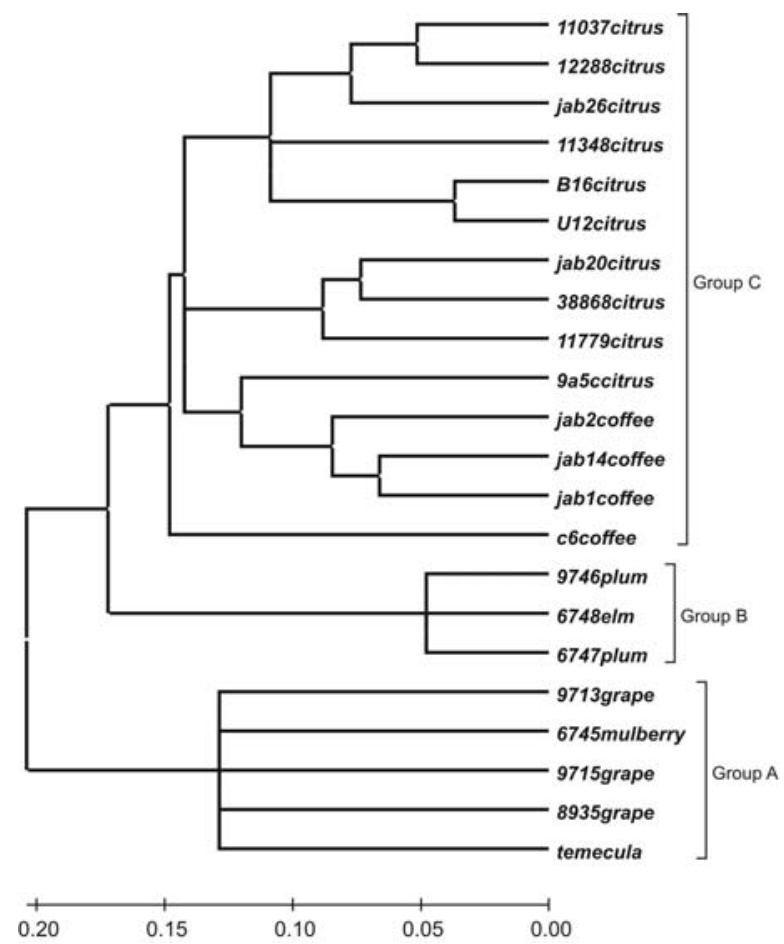

FIGURE 1- Phylogenetic relationships among $X$. fastidiosa strains obtained from same and different hosts. It can be verified that strains are grouped in three groups: grape-mulberry-temecula (A), plum-elm (B) and citruscoffee $(\mathrm{C})$.

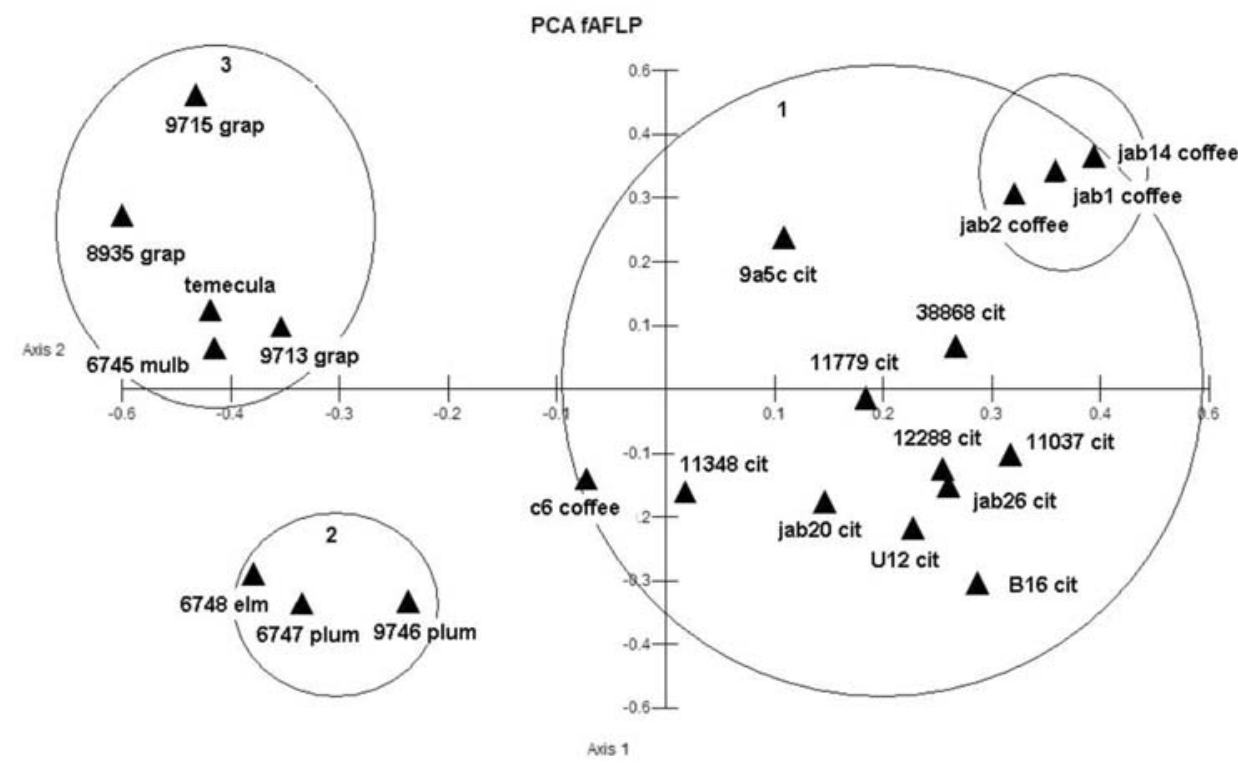

FIGURE 2 - Groupment of $X$. fastidiosa strains from same and different hosts. The strains formed three groups: Group 1 (citrus-coffee: 9a5c, 11779, 38868, Jab20, Jab26, 11348, U12, B16, 11037 and 12288; coffee: C6, Jab14, Jab2, Jab1), Group 2 (elm: 6748, plum: 6747, 9746), Group 3 (grape: 9713, 9715, 8935, mulberry: 6745 and Temecula). Cit: citrus, grap: grape and mulb:mulberry. 


\section{ACKNOWLEDGMENTS}

The authors thank FAPESP for financial support, Dr. Marcos Antônio Machado and Dr. Helvecio Della Coletta Filho (Centro APTA Citros Sylvio Moreira, Instituto Agronômico, Campinas, São Paulo, Brazil) for kindly providing of the $X$. fastidiosa strains used in this study.

\section{REFERENCES}

AARTS, H. J. M.; HAKEMULDER, A. M. A.; HOEF, V. Genomic typing of Listeria monocytogenesi strains by automated laser fluorescence analysis of amplified fragment length polymorphism fingerprint patterns. International Journal of Food Microbiology, Washington, v.49, p.95-102, 1999.

ARNOLD, C. et al. Predictive fluorescent amplified-fragment length polymorphism analysis of Escherichia coli: hightresolution typing method with phylogenetic significance. Journal of Clinical Microbiology, Washington, v.37 n.5, p.1274-1279, 1999.

AUSUBEL, F. M. et al. Current protocols in molecular biology, New York: J. Wiley and Sons, 1987. v.1.

BRAGARD, C. et al. Xanthomonas translucens from small grains : diversity and phytopathological relevance. Phytopathology, St. Paul, v.87, p.1111-1117, 1997.

CHANG, C. J.; and SCHAAD, N. W. Eletrophoretic protein profiles of total cell envelopes of xylem-limited plant pathogenic rickettsialike bacteria (RLB). Phytopathology, St. Paul, v.72, p. 730-733, 1982.

CHEN, J. et al. Genetic variation among Xylella fastidosa strains. Phytopathology, St. Paul, v.82, p.973-977, 1992.

CHEN, J. et al. Randomly amplified polymorphic DNA analysis of Xylella fastidosa Pierce's disease and oak leaf scorch pathotypes. Applied and Enviromental Microbiology, Washington, v.61, p.1688-90, 1995.

CHEN, J. et al. Two Xylella fastidiosa genotypes associated with almond leaf scorch on the same location in California. Phytopathology, St. Paul, v.105, n.7, p.708-714, 2005.

CHEN, J. et al. Use of 16S rDNA sequences as signature characters to identify Xylella fastidiosa. Current Microbiology, New York, 40:29-33. 2000

CIAPINA, L.P. Sequências repetitivas e sequenciamento do espaço intergênico dos genes 16S-23S rDNA acessando a diversidade genética em Xylella fastidiosa. 2001. 117 f. Tese (Doutorado em Agronomia) - Faculdade de Ciências Agrárias e Veterinárias, Universidade Estadual Paulista, Jaboticabal, 2001.
CLERC,A.; MANCEAU, C.; NESME, X. Comparison of randomly amplified polymorphic DNA with amplified fragment length polymorphism to assess genetic diversity and genetic relatedness within genospecies III of Pseudomonas syringae. Applied and Environmental Microbiology, Washington, v.64, n.4, p.1180 1187,1998

COLE, S.T. et al. Deciphering the biology of Mycobacterium tuberculosis from the complete genome sequence. Nature, London, v.393, p.537-544, 1998.

COLETTA-FILHO, H.D.; MACHADO, M.A. Evalution of the genetic strutucture of Xylella fastidiosa populations from different Citrus sinensis varieties. Applied and Environmental Microbiology, Washington, v.68, p.3731-3736, 2002;

CONTRERAS, J. D. V. Pecosita ou falsa mancha grasienta na Argentina. Laranja e Cia, Matão, v.31, p.6, 1992.

COUSINS, D. et al. Evaluation of four DNA typing techniques in epidemiological investigations of bovine tuberculosis. Journal of Clinical Microbiology, Washington, v.36, p.168-178, 1998.

DAVIS, M.J.; FRENCH, W.J.; SCHAAD, N.W. Axenic culture of the bacteria associated with phony disease of peach and plum leaf scald. Current Microbiology, New York, v.6, p.309-14, 1981.

GARNIER, M. et al. Citrus variegated chlorosis: serological detection of Xylella fastidiosa, the bacterium associated with the disease, p. 301-305. In: CONFERENCE OF THE INTERNATIONAL ORGANIZATION OF CITRUS VIROLOGISTS, 12., 1993, Riversidade. Proceedings... Riverside: University of California, 1993.

HOPKINS, D. L. Xylella fastidiosa: a xylem-limited bacterial pathogen of plants. Annual Review of Phytopathology, Washington, v.27, p. 271-90, 1989.

JANSSEN, P. et al. Evaluation of the DNA fingerprinting method AFLP as a new tool to bacterial taxonomy. Microbiology, Marlborough House, v.142, p.1881 - 1893, 1996.

KUMAR S, TAMURA, K.; NEI, M. MEGA3: Integrated Software for Molecular Evolutionary Genetics Analysis and Sequence Alignment. Briefings in Bioinformatics, Oxford, v.5, p.150-163, 2004.

LIU, F. et al. Distribution of allozymic alleles and genetic diversity in the American Barley Core Collection. Theoretical Applied Genetics, Stuttgart, v.102, p.606-615, 2001.

MAJEED, A. et al. AmpliBASE MT: a Mycobacterium tuberculosis diversity knowledgebase. Bioinformatics, Oxford, v.20, p.989992, 2004. 
MAJER, D. et al. The use of AFLP fingerprinting for the detection of genetic variation in fungi. Mycological Research, Amsterdan, v.100, p.1107-1111, 1996

MINSAVAGE, G. V. et al. Development of a polymerase chain reaction protocol for detection of Xylella fastidiosa in plant tissue. Phytopathology, St. Paul, v.84, p.456-61. 1994.

PURCEL, A. H.; HOPKINS, D. L. Fastidious xylem-limited bacterial plant pathogens. Annual Review Phytopathology, Washington, v.34, p.131-151, 1996.

RADEMAKER, J. L. W. et al. Comparison of AFLP and rep-PCR genomic fingerprinting with DNA-DNA homology studies: Xanthomonas as a model system. International Journal of Systematic and Evolutionary Microbiology, Marlborough House, v.50, p.665-677, 2000.

RESTREPO, S. et al. AFLP fingerprinting: an efficient techique for detecting genetic variation of Xanthomonas axonopodis pv. Manihotis. Microbiology, Marlborough House, v.145, p.107-114, 1999.

ROSSETTI, V. et al. Présence de bactéries dans le xylème d'orangers atteints de chlorose variégée, une nouvelle maladie des agrumes au Brésil. Compte Rendus de l' Academie des Sciences, Paris, v.30, p. 345-349, 1990.

SAMBROOK, J.; MANIATIS, T.; FRITSCH, E.F. Molecular cloning: laboratory manual. New York: Cold Spring Harbor Laboratory Press, 1989.
SCHAAD, N. W., et al. Xylella fastidiosa subspecies: $X$. fastidiosa subsp piercei, subsp. nov., $X$. fastidiosa subsp. multiplex subsp. nov., and $X$. fastidiosa subsp. pauca subsp. nov. . Systematics and Applied Microbiology, Marlborough House, v.27, p. 290-300, 2004.

SIMPSON, A.J. et al. The genome sequence of the plant pathogen Xylella fastidiosa. Nature, London, v. 406, p.151-157. 2000.

SWOFFORD, D. L. PAUP: phylogenetic analysis using parsimony and other methods.Version 4.0. Sunderland; Sinauer Associates, 1998.

VANEECHOUTTE, M. DNA Fingerprinting techniques for microorganisms: a proposal for classification and nomenclature. Molecular Biotechnology, New Jersey, v.6, p.115-142, 1996.

VANDAMME, P. et al. Polyphasic taxonomy, a consensus approach to bacterial systematics. Microbiological Reviews, Washington, v.60, n.2, p.407-438, 1996.

VOS, P. et al. AFLP: a new technique for DNA fingerprinting. Nucleic Acids Research, Oxford, v.23, p.4407-4414, 1995.

WELLS, J. M. Xylella fastidiosa gen. nov., sp. nov: gramnegative, xylem-limited, fastidious plant bacteria releted to Xanthomonas spp. International Journal of Systematic Bacteriology, Marlborough House v.37, p.136-153, 1987.

WICKERT, E. ; MACHADO M.A., LEMOS, E.M.G. Evaluation of the genetic diversity os Xylella fastidiosa strains from citrus and coffee hosts by single nucleotide polymorphism markes. Phytopathology, St. Paul, v.97, n.12, p.1543-1549, 2007. 